\title{
SOSIALISASI TEKNOLOGI HAND SANITIZER OTOMATIS UNTUK PENCEGAHAN COVID-19 DI KEC. KAWALU, KOTA TASIKMALAYA
}

\author{
Sutisna ${ }^{1}$, Aripin ${ }^{2} *$, Linda Faridah ${ }^{3}$, Edvin Priatna ${ }^{4}$, Anto Purwanto ${ }^{5}$ \\ 1,2,3,4 Jurusan Teknik Elektro, Fakultas Teknik, Universitas Siliwangi \\ ${ }^{5}$ Jurusan Ilmu Kesehatan Masyarakat, Fakultas Kesehatan Masyarakat, Universitas Siliwangi \\ *aripin@unsil.ac.id
}

\begin{abstract}
Kawalu District, Tasikmalaya City is one of the areas with high exposure to Covid-19 with 15 positive cases and 1 death case. Kawalu District has a fairly high social movement compared to other sub-districts because it is the center of the embroidery home industry with 1080 business units. Problems that occur in the Kawalu District is as follows: the frequency of activities for home embroidery industry business actors to travel to the red zone (Tanah Abang, Jakarta) is still very high and public awareness, especially employees of the home embroidery industry, for the prevention of covid-19 is still very low. Therefore, to deal with this incident, swift efforts from both the government and the community are needed so that the transmission of this virus does not spread widely to the community. One of the steps taken by the Tasikmalaya City Government to break the chain of transmission of COVID-19 is the mandatory appeal to wash hands regularly with soap and water (hand sanitizer) when going to activities. However, shared use of hand sanitizers in public places can potentially transmit Covid-19 due to physical contact between users and hand sanitizers. Based on this problem, the solution offered is to make an automatic hand sanitizer, users without having to make physical contact with the hand sanitizer. The purpose of this program is to increase the knowledge, insight and skills of the Community of the Dewan Kemakmuran Mesjis (DKM) in the manufacture and use of automatic hand sanitizers and then provide automatic hand sanitizers to several DKM in the Kawalu District, Tasikmalaya City. The number of participants is 20 community members of DKM Ummul Quro in Kec. Kawalu, Tasikmalaya City. The training will be held from 4 to 5 September 2021. This activity is carried out using training, practice, and mentoring methods. The method of socialization is to provide public awareness education of DKM to prevent the spread of Covid-19. The practical method is carried out by practicing directly the use of hand sanitizers, as well as providing assistance with hand sanitizers for DKM Ummul Quro. Technical assistance is carried out by sending student assistants to monitor partner activities from September 7 to 30, 2021. The results of the questionnaire show that the participants' interest in this activity is categorized as very good, especially for aspects of the need for hand sanitizers, practicality, and community empowerment. From the aspect of operating activities, it indicates that participants can use and operate hand sanitizers independently without assistance.
\end{abstract}

Keywords: automatic hand sanitizer, prevention of covid-19, community empowerment, skilled operation

\begin{abstract}
Abstrak
Kec. Kawalu, Kota Tasikmalaya termasuk daerah dengan paparan Covid-19 cukup tinggi sebanyak 15 kasus positif dan 1 kasus meninggal dunia. Kec. Kawalu mempunyai pergerakan sosial masyarakat cukup tinggi dibandingkan kecamatan yang lain karena pusat home industri bordir dengan 1080 unit usaha. Masalah yang terjadi di Kec. Kawalu adalah sebagai berikut: frekuensi aktivitas pelaku usaha home industri bordir untuk melakukan perjalanan ke zona merah (Tanah Abang, Jakarta) masih sangat tinggi dan kesadaran masyarakat terutama karyawan home industri bordir untuk pencegahan covid19 masih sangat rendah. Oleh karena itu, untuk menghadapi kejadian ini dibutuhkan upaya yang sigap baik dari pemerintah maupun masyarakat agar penularan virus ini tidak menyebar luas ke masyarakat. Salah satu langkah yang dilakukan Pemerintah Kota Tasikmalaya untuk memutus rantai penularan covid-19 adalah himbauan wajib untuk mencuci tangan secara teratur pakai sabun dan air (hand sanitizer) saat akan beraktivitas. Namun, penggunaan bersama hand sanitizer di tempat umum dapat berpotensi menularkan Covid-19 karena terjadinya kontak fisik antara pengguna dengan alat hand sanitizer. Berdasarkan masalah tersebut, solusi yang ditawarkan adalah membuat alat hand sanitizer otomatis, pengguna tanpa harus melakukan kontak fisik dengan alat hand sanitizer. Tujuan program ini adalah meningkatkan pengetahuan, wawasan dan ketrampilan masyarakat Dewan Kamakmuran Masjid (DKM) dalam pembuatan dan penggunaan hand sanitizer otomatis dan kemudian memberikan alat hand sanitizer otomas pada beberapa DKM di Kec. Kawalu, Kota Tasikmalaya. Jumlah peserta adalah 20 orang anggota masyarakat DKM Ummul Quro di Kec. Kawalu, Kota. Tasikmalaya.. Pelaksanaan pelatihan adalah dari tanggal 4 sampai 5 September 2021. Kegiatan ini dilakukan dengan metode pelatihan, praktek, dan pendampingan. Metode sosialisasi adalah memberikan edukasi kesadaran masyarakat DKM untuk pencegahan penyebaran Covid-19. Metode praktek dilakukan dengan mempraktekan langsung penggunaan alat hand sanitizer, serta memberikan bantuan alat hand sanitizer untuk DKM Ummul Quro. Pendampingan secara teknis dilakukan dengan menempatkan pendamping mahasiswa untuk memantau kegiatan mitra dari tanggal 7 sampai 30 September 2021. Hasil angket menunjukkan bahwa ketertarikan peserta dalam kegiatan ini terkatagori sangat baik terutama untuk aspek kebutuhan alat hand sanitizer, kepraktisan, dan pemberdayaan masyarakat. Dari aspek kegiatan pengoperasiannya, itu mengindikasikan bahwa peserta dapat menggunakan dan mengoperasikan hand sanitizer secara mandiri tanpa bantuan pendampingan.
\end{abstract}

Kata Kunci: hand sanitizer otomatis, pencegahan covid-19, pemberdayaan masyarakat, terampil operasi 


\section{Pendahuluan}

Meskipun sebagian masyarakat Kota Tasikmalaya sudah melaksanakan vaksinasi untuk mencegah penularan Covid-19, namun update terakhir tanggal 5 Mei 2021, Kota Tasikmalaya termasuk zona merah dengan jumlah terpapar 62 kasus terkonfirmasi positif covid-19 (Dinas Kesehatan Kota Tasikmalaya, 2021). Dari jumlah tersebut, Kec. Kawalu termasuk daerah dengan paparan Covid-19 cukup tinggi sebanyak 19 kasus positif. Hal ini disebabkan oleh pergerakan sosial masyarakat cukup tinggi dibandingkan kecamatan yang lain. Kec. Kawalu merupakan pusat home industri bordir yang memiliki 1080 unit usaha dan menyerap tenaga kerja 14.071 orang (Dinas Koperasi, UMKM, Perindustrian dan perdagangan, Kota Tasikmalaya, 2019). Tenaga kerja atau karyawan home industri bordir didominasi oleh perempuan dengan pendidikan tertingginya lulus Sekolah Menengah Atas (SMA). Produksi bordir Kawalu sebagian besar dipasarkan ke zona merah seperti Tanah Abang, Jakarta. Para pelaku industri bordir ini kerap melakukan perjalanan rutin ke daerah zona merah minimal satu kali dalam seminggu, sehingga aktivitas ini berpeluang sangat besar untuk terpapar covid-19. Oleh karena itu, untuk menghadapi kejadian ini dibutuhkan upaya yang sigap baik dari pemerintah maupun masyarakat agar penularan virus ini tidak menyebar luas ke masyarakat.

Secara konkrit, Pemerintah Kota Tasikmalaya telah melakukan langkah-langkah untuk menekan jumlah kasus inveksi dengan memutuskan rantai penyebaran covid-19 diantaranya yaitu memberikan himbauan untuk perilaku hidup bersih dan sehat (PHBS), penyemprotan desinfektan, isolasi mandiri, jaga jarak sosial, hindari berkumpul dengan jumlah banyak dan himbauan wajib menggunakan masker dan membersihkan tangan dengan air sabun (hand sanitizer) saat akan beraktivitas. Pencucian tangan adalah sangat baik untuk membunuh kuman/virus dalam upaya pencegahan dan pengendalian infeksi (Meisaroh dkk, 2021). Saat ini, di tempat-tempat umum seperti masjid, perkantoran, sekolah dan lain-lain menggunakan alat hand sanitizer dengan pencucian tangan melakukan kontak fisik pengguna dan alatnya, padahal setiap orang melakukan kontak fisik dengan alat tersebut (Utomo, 2020), sehingga kemungkinan besar virus yang menempel pada alat akan menular ke pengguna lain. Oleh karena itu, itu perlu alat hand sanitizer yang tanpa melakukan kontak fisik sehingga aman.

Tujuan program ini adalah meningkatkan pengetahuan, wawasan dan ketrampilan masyarakat Dewan Kamakmuran Masjid (DKM) dalam penggunaan hand sanitizer otomatis dan kemudian memberikan alat hand sanitizer otomas pada beberapa DKM di Kec. Kawalu, Kota Tasikmalaya.

\section{Metode}

1. Kegiatan Persiapan

Kegiatan persiapan pelatihan adalah sebagai berikut:

a. Observasi awal dilakukan dalam menganalisis masalah yang dihadapi oleh kecamatan mitra dalam menghadapi kasus wabah covid-19 yang sedang terjadi serta beberapa wawancara yang dilakukan bersama mitra DKM Ummul Qur.

b. Persiapan program meliputi penyusunan jadwal kegiatan yang disepakati bersama dan susunan acara pelatihan, dan menyiapkan perlengkapan penyelenggaraan pelatihan.

c. Rapat pemantapan materi dan pengecekan kebutuhan kegiatan bersama tim pengabdian.

\section{Pelaksanaan Kegiatan}

Pelaksanaaan kegiatan pembuatan dan penggunaan alat hand sanitizer diberikan kepada 20 orang dari masyarakat DKM Ummul Quro, di Kec. Kawalu, Kota. Tasikmalaya. Pelaksanaan kegiatan ini menggunakan metode pelatihan dan metode praktek (learning by doing) dengan memberikan praktek pembuatan dan penggunaan alat hand sanitizer. Tahapan pelaksanaan kegiatan adalah sebagai berikut:

a. Pelatihan Pembuatan Alat Hand Sanitizer

Pelatihan ini meliputi pengetahuan dasar pembuatan alat, penggunaan alat untuk mencegah covid-19 dan perawatan alat hand sanitizer otomatis.

b. Pendampingan

Kegiatan pendampingan kelompok mitra akan dilakukan dalam 2 (dua) bentuk sebagai berikut:

- Pendampingan secara teknis dilakukan dengan menempatkan pendamping mahasiswa yang dapat memantau kegiatan mitra dalam penggunaan alat hand sanitizer otomatis.

- Pendampingan secara teknis dilakukan dengan menempatkan pendamping secara periodik untuk memantau kegiatan mitra dan memberikan solusi atas permasalahan teknik produksi yang terjadi. 


\section{c. Monitoring dan Evaluasi}

Proses monitoring dan evaluasi secara periodik akan dilakukan sampai kelompok mitra bisa mandiri dalam menggunakan dan merawat produk alat hand sanitizer otomatis secara berkelanjutan sehingga secara keseluruhan tujuan, target dan luaran kegiatan pengabdian ini dapat tercapai dengan baik. Tabel 1 menunjukkan instrumen monitoring dan evaluasi pengabdian kepada masyarakat. Angket pelaksanaan kegiatan monitoring dilakukan setelah pendampingan dilakukan.

Tabel 1. Intrumen monev setelah kegiatan pengabdian kepada masyarakat

\begin{tabular}{cl}
\hline No & \multicolumn{1}{c}{ Item pertanyaan } \\
\hline 1 & Cara kerja hand sanitizer otomatis lebih mudah dari cuci tangan biasa \\
2 & Kegagalan hand sanitizer otomatis selama dua bulan digunakan setelah sosialiasi \\
3 & Keefektifan hand sanitizer otomatis untuk pencegahan Covid-19 \\
4 & Frekuensi penggunaan hand sanitizer otomatis selama dua bulan setelah sosialisasi \\
5 & Ketertarikan menggunakan hand sanitizer otomatis dari cuci tangan biasa \\
\hline
\end{tabular}

\section{Hasil dan Pembahasan}

Gambar 1 menunjukkan model hand sanitizer yang digunakan dalam kegiatan Pengabdian Kepada Masyarakat. Hand sanitizer otomatis ini dibuat menggunakan rangkaian sederhana yang terdiri dari modul sensor infra merah obstacle, arduino nano, rangkaian transistor switching dan pompa mini dengan tegangan DC, dan botol untuk tempat cairan Sensor infra merah berfungsi untuk mendeteksi tangan, yang bekerja jika ada halangan benda di depan sensor (Suraidi, 2020; Budiana, 2020). Handsanitizer otomatis mampu mengeluarkan cairan antiseptik saat mendeteksi adanya telapak tangan pada jarak $5 \mathrm{~cm}$ hingga 15 $\mathrm{cm}$. Pompa mini berfungsi untuk memompa cairan hand sanitizer di dalam botol. Hand sanitizer juga dilengkapi dengan rangkaian transistor switching yang berfungsi sebagai saklar untuk menghidupkan atau mematikan pompa celup dan botol. Setelah mendeteksi tangan, sensor infra merah memberikan perintah ke pompa celup melalui rangkaian transistor switching untuk memompa cairan antiseptik yang ada di dalam botol untuk kemudian dikeluarkan melalui selang (Wijayanto, 2021). Pompa akan menyala selama 1,5 detik kemudian mati. Cairan yang digunakan adalah jenis encer karena jika terlalu kental agak susah untuk dipompa karena pompa yang digunakan berdaya kecil.

Gambar 2 menunjukkan pelaksanaan kegiatan sosialisasi teknologi hand sanitizer otomatis untuk pencegahan Covid-19 Di Kec. Kawalu, Kota Tasikmalaya. Kegiatan pengabdian ini dilakukan melalui pelatihan dan praktek penggunaan hand sanitizer di Kec. Kawalu, Kota Tasikmalaya. Pelatihan dan praktek dilaksanakan pada hari Sabtu dan Minggu, 4 - 5 September 2021. Para peserta yang hadir dalam kegiatan tersebut sebanyak 20 orang dari masyarakat DKM Ummul Quro, di Kec. Kawalu, Kota. Tasikmalaya.

Tabel 2 menunjukkan data pendapat peserta yang mengikuti pelaksanaan kegiatan sosialisasi teknologi hand sanitizer otomatis. Kegiatan ini merupakan evaluasi dengan melakukan wawancara dengan peserta sosialiasi tentang hand sanitizer otomatis yang telah dibuat. Evaluasi ini terdiri dari pertanyaan-pertanyaan tentang efesiensi dan efektivitas alat Handsanitizer otomatis. Semua peserta memberikan pendapat terhadap pertanyaan berkatagori sangat baik. Untuk pertanyaan tentang perbandingan cara kerja hand sanitizer otomatis dan tidak otomatis dan juga pencucian manual, peserta memberikan jawaban bahwa hand sanitizer cara kerjanya praktis hanya dengan menggerakkan tangan cairan dari alat hand sanitizer keluar. Ketika membandingkan dengan hand sanitizer tidak otomatis, cairan akan keluar dari alat jika komponen alat ditekan, namun itu mempunyai kelemahan bahwa alat yang ditekan disentuh oleh orang berbeda sehingga virus Covid-19 bisa ditularkan melalui tempat penekanan alat hand sanitizer. Tempat yang digunakan untuk menyimpan hand sanitizer otomatis adalah di serambi pintu masuk masjid dan madrasah. Penempatan ini sebenarnya tidak aman terhadap air hujan, sehingga beberapa komponen listrik dari alat hand sanitizer rentan terhadap konsleting listrik atau komponen listrik rusak jika basah terkena air (Darmana, 2018). Namun selama dua bulan digunakan oleh masyarakat DKM Ummul Quro alat hand sanitizer tidak mengalami kendala berarti dan alat tetap aman dan kering. 


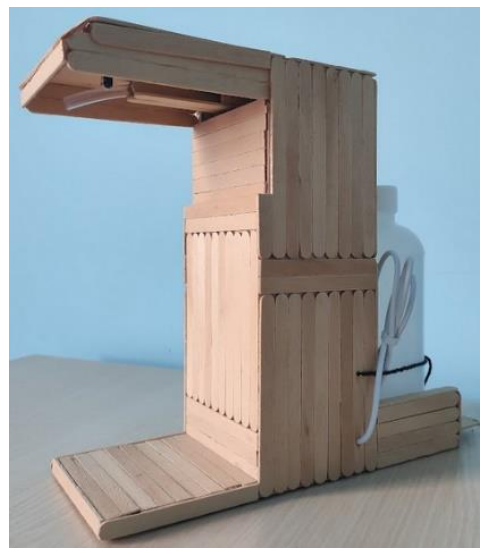

Gambar 1. Model hand sanitizer yang digunakan dalam kegiatan Pengabdian Kepada Masyarakat.
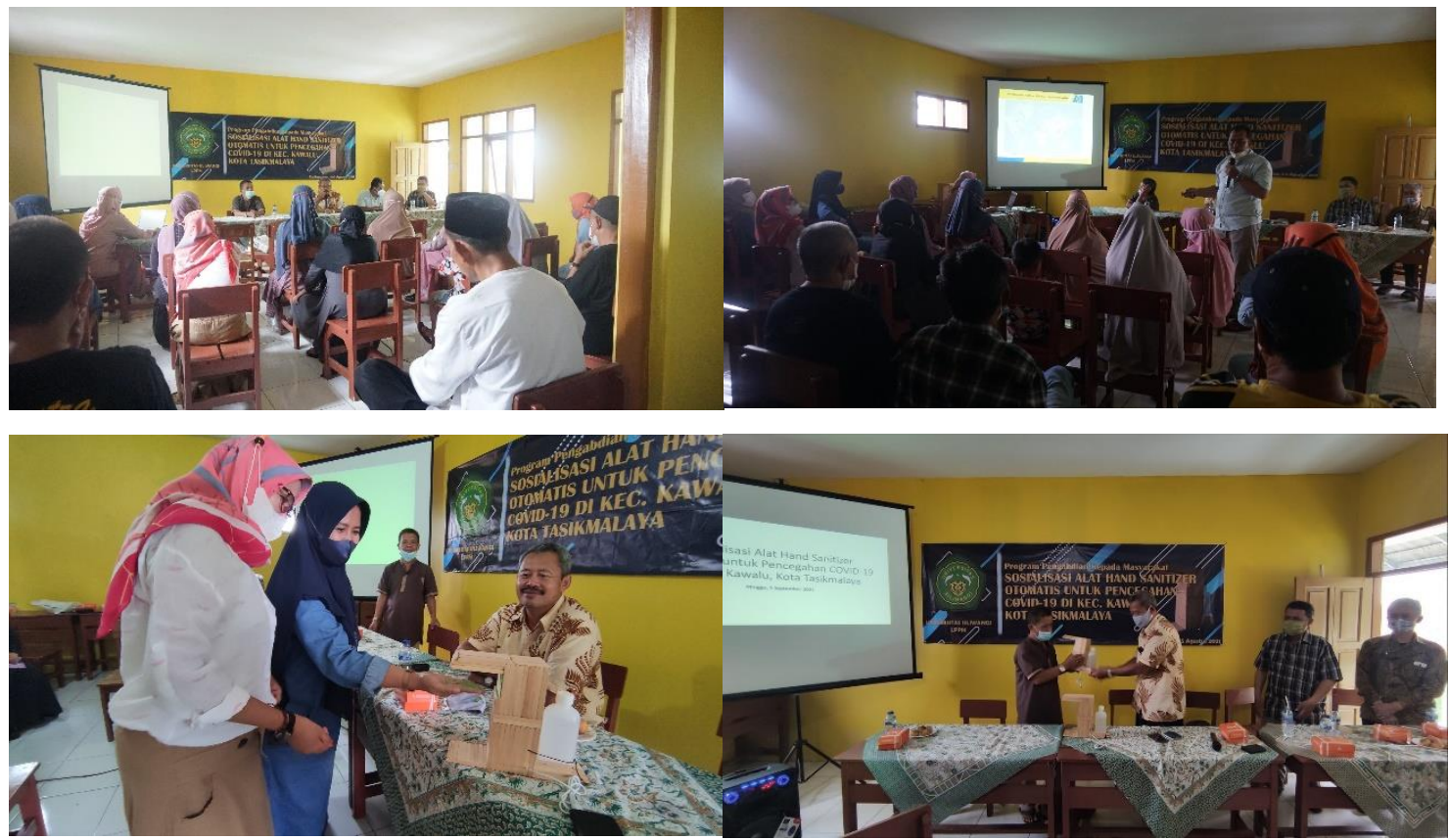

Gambar 2. Pelaksanaan kegiatan sosialisasi teknologi hand sanitizer otomatis untuk pencegahan Covid-19 Di Kec. Kawalu, Kota Tasikmalaya.

Tabel 2. Data ketercapaian pelaksanaan kegiatan sosialisasi teknologi hand sanitizer otomatis.

\begin{tabular}{lcc}
\hline \multicolumn{1}{c}{ Item pertanyaan } & Skor & Katagori \\
\hline Cara kerja hand sanitizer lebih mudah dari cuci tangan biasa & 3,86 & Sangat baik \\
Kendala hand sanitizer selama digunakan setelah sosialiasi & 3,63 & Sangat baik \\
Kebutuhan hand sanitizer di Kec. Kawalu & 3,62 & Sangat baik \\
Frekuensi penggunaan hand sanitizer selama dua bulan setelah & 3,56 & Sangat baik \\
sosialisasi & & \\
Hand sanitizer untuk pemberdayaan masyarakat & 3,71 & Sangat baik \\
Mendorong kemandirian masyarakat & 3.24 & Sangat baik \\
\hline
\end{tabular}

Dengan pemberlakuan status new normal, aktivitas masyarakat Kec. Kawalu untuk melakukan perjalanan bisnis ke Tanah Abang semakin tinggi, sehingga akan berakibat pada peningkatan penularan covid-19 pada masyarakat sekitarnya. Berdasarkan hal tersebut, diperlukan aksi nyata untuk mengajak masyarakat agar senantiasa waspada terhadap penyebaran virus ini yakni memfasilitasi masyarakat dengan alat hand sanitizer otomatis gratis sekaligus bentuk edukasi bagi masyarakat betapa pentingnya menjaga 
kewaspadaan sejak dini. Menyikapi kejadian tersebut, masyarakat DKM Ummul Quro, di Kec. Kawalu, Kota memberikan jawaban bahwa sangat dibutuhkan alat hand sanitizer di lingkungan warga DKM Ummul Quro untuk mencegah penularan Covid-19.

Ketika pertanyaan diajukan tentang frekuensi penggunaan hand sanitizer di DKM Ummul Quro, itu menunjukkan skor dengan katagori sangat baik. Itu bisa dipahami bahwa jumlah pengguna hand sanitizer dari jamaah masjid dan jamaah pangajian Ummum Quro menjadi indikator frekuensi penggunaan hand sanitizer. Berdasarkan hasil wawancara dengan ketua DKM Ummum Quro, itu diketahui bahwa dalam satu hari rata-rata jamaah masuk masjid untuk menunaikan shalat fardhu sebanyak 60 orang, sehingga dalam dua bulan berjumlah 3600 orang telah menggunakan alat hand sanitizer. itu belum termasuk jemaah pengajian ibu-ibu yang biasa dilaksanakan dua minggu sekali. Dari azas kemanfaatan, itu berarti bahwa alat yang dibuat telah melindungi masyarakat dalam jumlah banyak dari penyebaran virus Covid-19. Selanjutnya, peserta sosialisasi juga tertarik terhadap pertanyaan tentang munculnya aspek pemberdayaan masyarakat dengan dibuatnya alat hand sanitizer. Saat ini sebagian masyarakat sekitar DKM Ummul Quro telah mengembangkan usaha pembuatan cairan antiseptik dari daun herbal alami. Pandangan masyarakat menunjukkan bahwa ini merupakan peluang untuk memasarkan produk cairan antiseptik pencuci tangan dengan dibuatnya alat ini, sehingga jika cairan pencuci tangan yang dibuatnya bisa dikembangkan dan jangkauan pemasaran untuk cairan antisptik ini lebih luas. Ini menjadi kebutuhan pokok dalam mengembangkan aspek pemberdayaan masyarat untuk menjual cairan pencuci tangan melalui alat hand sanitizer. Pada pertanyaan tentang kemampuan mendorong kemandirian masyarakat, itu mendapatkan skor 3,24 berkatagori sangat baik, namun lebih kecil dari skor untuk pemberdayaan masyarakat. Masyarakat berpikir bahwa masyarakat ragu untuk memulai menggunakan alat hand sanitizer. Masyarakat menganggap bahwa dengan adanya alat ini setelah kegiatan pengabdian kepada masyarakat selesai, masyarakat DKM harus membeli sendiri ini cairan hand sanitizer dan mereka mempunyai beban untuk menyediakan cairan hand sanitizer secara berkelanjutan.

\section{Kesimpulan}

Berdasarkan hasil kegiatan dan pembahasan, maka kesimpulan adalah sebagai berikut:

a. Sosialisasi keselamatan penggunaan alat hand sanitizer bagi warga masyarakat DKM Ummul Quro merupakan kegiatan yang memiliki kontribusi yang besar bagi masyarakat untuk meningkatkan kesadaran pentingnya menjaga kesehatan dari penularan Covid-19 dengan membersihkan tangan setiap melakukan aktivitas ibadah di masjid dan pengajian di madrasah DKM Ummul Quro.

b. Secara keseluruhan, penyerapan materi sosialisasi oleh peserta dikatagorikan terampil sangat baik dalam penggunaan alat hand sanitizer. Sesuatu yang menarik bagi peserta adalah bahwa kegiatan sosialiasi penggunaan alat hand sanitizer sesuai dengan situasi dan kondisi yang terjadi saat ini untuk pencegahan penyebaran Covid-19. Di samping itu, dengan adanya alat hand sanitizer ini, itu memberi peluang usaha untuk pemberdayaan masyarakat di DKM Ummul Quro dalam membuat cairan antisptik dari daun herbal alami yang selama ini sudah ada.

b. Dengan tujuan membawa kenangan positif kepada masyarakat DKM Ummul Quro, diakhir kegiatan, itu dihibahkan tiga alat hand sanitizer yang diperuntukan untuk masjid, madrasah, dan sekolah yang mempunyai pergerakan dan interaksi jamaah dan siswa sekolah, dan diharapkan bisa dimanfaatkan sebagai fasilitas untuk mencegah penularan Covid-19 di Kec. Kawalu, Kota Tasikmalaya.

\section{Ucapan Terima Kasih}

Penulis mengucapkan terima kasih kepada Universitas Siliwangi yang telah mendanai kegiatan pengabdian kepada masyarakat melalui Skema Kesehatan (PbBM-SK) Tahun 2021. Di samping itu, penulis juga ingin mengucapkan banyak terima kasih kepada Dewan Kemakmuran Mesjid Ummul Quro, Kelurahan Gunung Gede, Kec. Kawalu, Kota Tasikmalaya atas kerjasamanya menyediakan tempat untuk acara pengabdian kepada masyarakat ini.

\section{Daftar Pustaka}

Budiana B, A. Sani, D. Pamungkas, M. Wahyudi, 2020. Pembuatan Alat Otomatis Hand Sanitizer sebagai Salah Satu Antisipasi Penyebaran COVID-19 di Politeknik Negeri Batam, Journal of Applied Electrical Engineering, Vol. 4, hal. 40 - 43. 
Darmana T., Erlina, S. Hidayat, R. Diantari, T. Ratnasari, Jumiati, S. Soewono, (2018). Sosialisasi bahaya dan keselamatan penggunaan listrik di kelurahan duri Kosambi, Cengkareng, Terang, Vol. 1, hal. $96-104$.

Dinas Kesehatan Kota Tasikmalaya, (2021).

Dinas Koperasi, UMKM, Perindustrian dan Perdagangan, Kota Tasikmalaya, (2019).

Meisyaroh M, S. Sakinah, Asnuddin, S. Nurdin, Hasrul, Murtini, 2021. Penyuluhan Cuci Tangan Pakai Sabun dan Penanganan COVID-19, Jurnal Kreativitas PPM, Vol. 4, hal. $234-239$.

Suraidi, (2020). Begini Cara Membuat Hand Sanitizer Otomatis, Pintar opini Untar, Vol. 1, hal. 17 - 21.

Utomo, A.P., W. Primaningtyas, M. M. Ahmad, (2020). Pelatihan Pembuatan Hand Sanitizer dan Aplikasi Pola Hidup Bersih di SMK Negeri 4 Surabaya dalam Menyikapi Pandemi Covid-19, Eduvicilia, Jurnal Pengabdian Pada Masyarakat, Vol. 1, hal. 111 - 118.

Wijayanto,H., A. P. Nevita, H.A. Munawi, (2021). Perancangan Sistem Otomatisasi Hand Sanitizer Berbasis Sensor Infrared Barrier Module, Jurnal NOE, Vol 4, hal. 18 - 23. 